\title{
Does Financial Institution Support for Economic Growth? A Case of Nepal
}

\author{
Bharat Ram Dhungana $\star$
}

\begin{abstract}
This paper examines the causality of economic growth and financial institutions with reference to Nepalese economy and determines whether financial institutions supports for economic growth or not. The empirical analysis shows that there is existence of long run association among the variables of gross domestic product $(G D P)$, broad money (M2) and domestic credit to private sectors (DCPS). Moreover, vector error correction model (VECM) also suggests for the validity of the long run association among variables. The Granger causality and Wald statistics test do not find any short run causal relationship. The empirical result shows that there is a long-run association between financial institutions and economic growth of Nepal. Thus, a sound financial system helps to promote financial institutions in the country that supports for economic growth of the nation in the long run. The regulatory authority and financial institutions should accelerate financial reforms to improve the efficiency of financial system that helps to stimulate adequate capital formation and investment in the productive sectors.
\end{abstract}

Keywords: Economic growth, financial system, granger causality, regulatory authority, and vector error correction model.

\section{BACKGROUND}

A well-developed financial institution supports for capital formation and encourages investment by identifying and financing productive business opportunities. Economists have generally reached into a consensus on the significant role of financial institutions in economic development. Schumpeter (1934) concluded that banking sector is an engine of economic growth through its funding of productive investment. Thus, financial institution is considered as a key factor for the economic growth of the nation.

A country without sound financial system may have to face many problems and that ultimately hinders for the economic development of the nation. So, there is no debate on requirement of good financial system in the country that helps to promote the economic development. The financial institution is one of the significant components of the financial system, plays crucial role for the enhancement of a national economy through efficient resource management for business and

* Mr. Dhungana is Ph.D. Research Scholar, BHU, Varanasi, India and Lecturer, School of Business, Pokhara University, Lekhnath, Kaski, Nepal.Email: dhunganabharat.pu@gmail.com 
development project that are essential for economic development. It is, therefore, argued that an effective and efficient financial system is mandatory for the nation's economic development process. The economic development can be measured by growth indicators such as GDP, GNP and per capita income. There are number of indicators that may be applied to measure the link between financial development and economic growth. Narrow money (M1) to GDP ratio, broad money (M2) to GDP ratio, bank credit and credit to private sector are some of the widely used financial deepening indicators to measure their effects on economic development. A strong correlation between these development indicators may lead to economic growth of the nation with the development of financial sectors.

The main objective of this study is to examine short run and long run causal relationship between financial institutions and economic growth with reference to Nepalese economy. The paper is based on the secondary data published by various national and international government institutions however, Economic Survey and World Bank Report are the major sources of data since 1975 to 2012.

\section{LITERATURE REVIEW}

Kharel and Pokhrel (2012) analyzed that Nepal's financial structure matter for economic growth or not. The empirical results using Johansen's cointegrating vector error correction model suggest that banking sector plays a key role in promoting economic growth compared to capital market in Nepal. It may be either the size of capital market is too small to seek the relationship or it is weakly linked to real economic activities. The result implies that the policy should focus on banking sector development by enhancing its quality and outreach as it promotes economic growth in Nepal.

Westermann (2012) examined the linkages between sectoral output growth and financial development in Nepal. The research concluded that while services react positively to increases in domestic lending, both agriculture and manufacturing are largely unaffected. The services sector shows a positive response that increases in magnitude and the manufacturing sector, as well as agriculture show mainly insignificant reactions.

Maskay and Subedi (2009) analyzed development of the Nepalese financial system. The paper concluded that despite significant financial deepening in the context of financial liberalization and integration with the external economy, there is still scope for geographically balanced financial development. For addressing these challenges in a comprehensive manner, the study proposed initiating the development of a financial sector master plan.

Abu-Bader and Abu-Qarn (2008) examined the causal relationship between financial development and economic growth for six Middle Eastern and North African countries within a quadvariate vector autoregressive framework. The empirical results reflected strong evidence for causality running from financial development to economic growth but no causality in the other direction. The findings made by the researchers suggested that there is need to accelerate the financial 
reforms that will help to improve the efficiency of financial system to stimulate savings, investment and consequently, long-term economic growth of the nation.

Bhetuwal (2007) assessed financial liberalization and financial development in Nepal. Financial development is not the outcome of only policy changes in the financial sector, but also depends on the demand for financial services in the economy. The development of the financial sector is the backbone for economic development of a country. But it cannot be achieved in isolation with the other sectors of the economy. Simultaneous growth in all the sectors of the economy can increase more demand of financial services and it can stimulate financial development. Unidirectional causality from financial liberalization to financial development found from the Granger causality test depicts this practical situation.

Shrestha (2005) examined financial liberalization in Nepal. He concluded that financial liberalization is positively associated with growth, but negatively associated with income equality and financial stability. But the study did not find any causal relationship between financial development and economic growth in Nepal. Hence, the financial liberalization in Nepal has not facilitated a financial development to the extent that contributed significantly to the economic development of the country.

The relationship between financial development and economic growth are controversial both from the theoretical and empirical perspectives. Some economic researchers argue that finance precedes economic growth while on the other hand some argue that economic growth leads to financial development. Levine (2004) argued that the costs of processing and acquiring information are greatly reduced by financial intermediaries and this improves resource allocation in the economy. This argument reinforces what Schumpeter (1934) said about the same relationship. This line of thinking was also investigated by Blackburn and Hung (1996). Greenwood and Jovanovic (1990) came up with a formal dynamic model for the relationship between finance and growth. Their results illustrated that financial development and economic growth actually reinforce each other.

Calderon and Liu (2003) examined pooled data of 109 countries to find out the direction of causality between financial development and economic growth by employing Gewke Decomposition test. They found the five distinct results as:

- Financial Development generally leads economic growth.

- Bi-directional causality between financial development and economic growth.

- In developing countries, financial deepening causes more to growth than industrial countries.

- Financial development has larger effect on economic growth in the long run.

- Financial deepening contributes economic growth through more rapid capital accumulation and productivity growth.

Demrgic-Kunt and Levine (2001) assessed the relationship between financial structure and economic development of 150 countries. Their study provided an international comparison of economic development and the development of bank and non-bank financial institutions as well as stock market. They have compared economic development of countries with bank-based and 
market-based financial system, and their legal, regulatory, tax and macro-economic determinants of financial structure. They found:

- Banks, non-banks and stock markets are larger, more active and efficient in richer countries.

- Financial systems are more developed in richer countries than in developing countries on average.

- Financial systems tend to become more market oriented as a country becomes richer.

Bhusal (2001) analyzed the long run relationship between financial development and economic growth is existed or not. The study concluded that the financial system has a key role in the development process of Nepal and its role has been increasing more in a liberalized system. To detect the impact of development of financial system in the economic development of Nepal, further empirical investigations are necessary.

Beck, Levine and Loyaza (2000) assessed the empirical relationship between the level of financial intermediary development and (i) economic growth, (ii) total factor productivity growth, (iii) physical capital accumulation, and (iv) private savings rate by using pure cross-country instrumental variable estimator to extract the exogenous component of financial intermediary development, and a new panel technique to control for biases associated with simultaneity and unobserved country specific effects. They concluded that financial intermediaries exert a large positive impact on total factor productivity growth and the long run links between financial intermediary development and both physical capital growth and private savings rates are weak.

Khan and Senhadji (2000) suggested that financial depth is measured by four alternative indicators: domestic credit to the private sector as a share of GDP (fd1), fd1 plus the stock market capitalization as a share of GDP (fd2), fd2 plus the private and public bond market capitalization as a share of GDP (fd3) and stock market capitalization (stock). They examined the empirical evidence on the relationship between financial development and economic growth. Their results confirmed the strong positive and statistically significant relationship between financial depth and growth.

A comprehensive index of financial development was proposed by Gelbard and Leite (1999). They suggested that a thorough assessment of financial system should consider at least six areas: the market structure and competitiveness of the system, the availability of financial products, the degree of financial liberalization, the institutional environment under which the system operates, the degree of integration with foreign financial markets (financial openness) and the degree of sophistication of the instruments of monetary policy. The conclusion is that the higher the value of the index, the higher is the degree of financial development and both the level and the change in financial development have an effect on per capita GDP growth.

King and Levine (1993a) related GDP per capita growth to nine different indices of financial deepening: narrow money to GDP, broad money to GDP, quasi money to GDP, central bank domestic credit to GDP, commercial bank domestic credit to GDP, gross claims on the private sector to GDP, commercial bank domestic credit to total domestic credit, claims on non-financial 
private sector to total domestic credit and claims on the private sector by non-deposit money banks to GDP.

King and Levine (1993b) again used four measures of financial development indicators. The first is to measures the size of financial intermediaries and equals liquid liabilities of the financial system (currency plus demand and interest bearing liabilities of banks and non-bank financial Intermediaries) divided by GDP. The second is to measure of financial development, degree to which the central bank versus commercial banks is allocating credit. This ratio is calculated as bank credit divided by bank credit plus central bank domestic credit. The third measure of financial development is the ratio of credit allocated to private enterprises to total domestic credit. The fourth measure is credit to private enterprises divided by GDP. They find that there is a strong positive relationship between each of the four financial indicators and the three growth indicators (long-run real per capita growth rates, capital accumulation and productivity growth). There is a statistically significant and economically large empirical relationship between the level of financial development and future growth indicators.

Goldsmith (1969) empirically analyzed the financial structure and economic growth of 35 countries over the period 1860 to 1963 . Financial structure of different countries vary with respect to the relative types of existing financial instruments and institutions, degree of concentration of financial intermediaries, volume of financial instruments relative to national wealth, national income, capital formation and savings. He found a positive correlation between financial development and the level of economic activity; as the size of the financial sector enlarges relative to the size of the economy, the country develops.

A cross-country case study by Cameron and et al. (1967) showed the historical relationship between the development of banking system and the industrialization process of developed countries. The studies while evaluating the economic, legal and financial linkages between industries and banking systems, gave a wide range of reasoning on the development of financial system during pre-industrialization period. The subjective evaluation of banking system performance concludes that banking system had played significant positive role in the industrialization process as well as its role to induce growth.

\section{The Status of Nepalese Financial Institutions}

Financial institutions are the most important institutions for the economic growth of the nation. The Nepalese financial institutions consists bank and non-bank financial institutions. The NRB has classified the Nepalese financial institutions into commercial banks (Class A), development banks (Class B), finance companies (Class C) and micro-finance development banks (Class D) on the basis of minimum paid up capital.

\section{Growth of Financial Institutions in Nepal}

The history of banking in Nepal is not very old, as a first bank, Nepal Bank Limited (NBL) was established in 1937. With the establishment of Nepal Rastra Bank (NRB), as a Central Bank of the 
country in 1956, the Nepalese financial system gained momentum. Industrial Development Bank was established in 1957 as the first development bank, which was converted into Nepal Industrial Development Corporation (NIDC) in 1959. Within a decade of the establishment of Nepal Rastra Bank, a number of financial institutions came into operation. Rastriya Banijya Bank (RBB), the second commercial bank, fully owned by the government was established in 1966. Agricultural Development Bank (ADBN) came into operation in 1968 with the objective of providing longterm and medium-term credit facilities to agriculture sector. After adaptation of the liberalization in Nepal, financial sector has made a tremendous progress both in terms of the number of bank and clients of financial services. The growth and development of Nepalese financial institutions has been presented in table 1 .

The trend of establishment of commercial banks was high compared to the development banks till the date of 2004. The number of development banks and finance companies has been established in Nepal after 1990. Till the mid January, 2014, total number of class 'A' to class 'D' bank and financial institutions including Savings and Credit Cooperatives and Financial Intermediary Nongovernment Organizations, reached to 258 however, this number has been decreased recently due to merger of few financial institutions.

Table 1: Growth and Development of Financial Institutions in Nepal

\begin{tabular}{lcccccccccc}
\hline Types of & \multicolumn{10}{c}{ Mid July } \\
\cline { 2 - 6 } & 1980 & 1985 & 1990 & 1995 & 2000 & 2005 & 2010 & 2012 & 2013 & $2014^{*}$ \\
Institutions & & & & & & & & & & \\
\hline CBs & 2 & 3 & 5 & 10 & 13 & 17 & 27 & 32 & 31 & 31 \\
DBs & 2 & 2 & 2 & 3 & 7 & 26 & 79 & 88 & 86 & 87 \\
FCs & 0 & 0 & 0 & 21 & 45 & 60 & 79 & 70 & 59 & 59 \\
MFDBs & 0 & 0 & 0 & 4 & 7 & 11 & 18 & 24 & 31 & 35 \\
SCCs & 0 & 0 & 0 & 6 & 19 & 20 & 15 & 16 & 15 & 15 \\
FINGOs & 0 & 0 & 0 & 0 & 7 & 47 & 45 & 36 & 31 & 31 \\
Total & 4 & 5 & 7 & 44 & 98 & 181 & 263 & 266 & 253 & 258 \\
\hline
\end{tabular}

Source: Banking and Financial Statistics of Various Issues and List of BFIs, NRB.

Notes: CBs: Commercial Banks; DBs: Development Banks; FCs: Finance Companies; MFDBs: Micro-finance Development Banks; SCCs: Saving and Credit Cooperatives and FINGOs: Financial Intermediary Non-government Organizations. *Mid January

\section{DATA AND METHODOLOGY}

There is need to test stationarity of the variables for which unit root test in time series data, mainly Augmented Dickey Fuller (ADF) test method has been applied. The causal relationship between financial institutions and the economic growth has been tested with the help of Granger Causality Test and Johnson Co-integration Test. The regression model and VAR model have been applied to forecast and test long run association between the variables. 


\section{Key Variables Used in the Model}

The number of indicators may have direct and indirect relationship between financial institutions and the economic growth. The problem of choosing from the vast number of applicable financial development indicators, however, the researcher has selected the following major variables to find the causal relationship between financial development and economic growth:

\section{Gross Domestic Product (GDP)}

GDP is the market value of the final goods and services produced within a country in a given time period. GDP per capita is often considered as the standard indicator rather than taking in total basis because it may vary as per the size and population of the country. The annual growth of GDP or GDP per capita is more appropriate in econometric analysis.

\section{Broad Money (M2) to GDP}

Broad money is the major indicator of financial deepening. A higher ratio indicates greater financial sector development in the nation. It denotes that people prefer to hold monetary assets, if they feel more confident and convenient to hold such assets with a view of maintaining liquidity, risk, and return. Looking at the growth trend of M2/GDP ratio, one can easily observe that the growth pattern is in favor of increasing financial deepening.

\section{Gross Capital Formation (GCF) to GDP}

Gross capital formation (formerly gross domestic investment) consists of outlays on additions to the fixed assets of the economy plus net changes in the level of inventories. Fixed assets include land improvements, plan, machinery and equipment purchase, the construction of roads and railways including schools, offices, hospitals, private residential dwellings and commercial as well as industrial buildings. Inventories are stocks of goods held by firms to meet temporary or unexpected fluctuations in production or sales and work in progress.

\section{Domestic Credit to Private Sector (DCPS in Percent of GDP)}

Domestic credit to private sector (DCPS) refers to financial resources provided to the private sector, such as through loans, purchases of non-equity securities, and trade credits and other accounts receivable that establish a claim for repayment.

\section{Unit Root Test}

A test of stationarity that has become widely popular over the past several years is the unit root test. Stationarity is an essential test for time series data, and a time series data is said to be stationary if it has time invariant mean and variance. This test will examine the order of integration of data. If the series is non-stationary, it is said to have unit root in its characteristic equation. Non-stationary time series data should be transformed into stationary by differencing. The Dickey-Fuller tests described above assume that the disturbances in the model as stated are white noise. An extension which will accommodate some forms of serial correlation is the Augmented Dickey-Fuller (ADF) test. The ADF test is the same one as above, carried out in the context of the model:

$$
\Delta Y_{t}=\beta_{1}+\beta_{2 t}+\delta Y_{t-1}+\sum_{i=1}^{m} \alpha_{i} \Delta Y_{t-i}+\varepsilon_{t}
$$


Where, $\varepsilon_{t}$ is a pure white noise error term.

\section{Causality Test}

In an econometric model, causality refers to direction of change in one variable due to change in another variable. Not only one directional causality but also bi-directional relationship between the variables may exist in the system. The economic growth is explained by financial development variables and if financial development causes growth and growth causes financial development then it can be possible that the coefficient is statistically significant. In such situation, Granger causality test ascertains the bi-directional causality.

The Granger causality test assumes that the information relevant to the prediction of the respective variables size and structure of financial institutions and economic growth is contained solely in time series data on these variables. The objective of the research work is to examine whether development of financial institutions leads economic growth or growth leads the development of financial institutions. The development of financial institutions variables are depository and nondepository financial institutions. The causality test provides the support of economic growth led to the development of financial institutions.

$$
\begin{aligned}
& X_{t}=\alpha_{0}+\sum_{i=1}^{p} \alpha_{i} X_{t-i}+\sum_{i=1}^{p} \beta_{i} Y_{t-i}+\mu_{1 t} \\
& Y_{t}=\delta_{0}+\sum_{i=1}^{p} \delta_{i} X_{t-i}+\sum_{i=1}^{p} \gamma_{i} Y_{t-i}+\mu_{2 t}
\end{aligned}
$$

\section{Cointegration Test}

Engle and Granger (1987) pointed out that a linear combination of two or more non-stationary series may be stationary. If such a stationary linear combination exists, the non-stationary time series are said to be cointegrated. The Johansen cointegration test has been applied for long-run equilibrium relationship among the variables has been existed or not.

$$
\Delta Y_{t}=\gamma Y_{t-1}+\sum_{i=1}^{p} \beta_{i} \Delta Y_{t-1}+e_{t}
$$

\section{Vector Error Correction Model (VECM)}

VECM is an econometric model applied for testing long-run relationship among the variables. This model is a category of multiple time series model that directly estimates the speed at which a dependent variable $\mathrm{Y}$ returns to equilibrium after a change in an independent variable $\mathrm{X}$. VECM is a theoretically-driven approach useful for estimating long term effects of one time series on another.

$$
\Delta Y_{t}=\alpha_{0}+\alpha_{1 i} \sum_{i=1}^{m} \Delta x_{t-1}+\alpha_{2 k} \sum_{k}^{n} \Delta z_{t-k}+\alpha_{3} \vartheta_{t-1}+\varepsilon_{t}
$$




\section{RESULTS AND DISCUSSION}

\section{Unit Root Test}

The researcher has tested the unit root by using ADF test for each series of the variable individually whether the data has stationarity or not. The lag length selection has been set automatic based on Schwarz Information Criterion (SIC) and the maximum length of lag is 9 by default. The researcher has presented the outcome of the unit root test through the table 2.

Since the absolute calculated value of GDP and GCF are greater than the corresponding McKinnon critical values at the level of the variables, so null hypothesis has been rejected. It means that there is no unit root for GDP and GCF and the data of the variables are stationary. But in the case of M2 and DCPS, the absolute calculated value of M2 and DCPS are lower than the corresponding McKinnon critical values at the level of the variables, so null hypothesis cannot be rejected. It means that there is unit root for the M2 and DCPS at the level and again tested at first difference, their absolute calculated value are greater than the corresponding McKinnon critical value at the first difference of the variables, so null hypothesis has been rejected. It denotes that there is no unit root at the first difference. So, we need to convert the non-stationary data of M2 and DCPS into stationary by using first difference.

Table 2: Outcome of Unit Root Test

\begin{tabular}{cccc}
\hline & \multicolumn{2}{c}{ Augmented Dickey-Fuller (ADF) Test Statistic } & Degree of \\
\cline { 2 - 3 } Series & Level & First Difference & $\begin{array}{c}\text { Degration } \\
\text { Integran }\end{array}$ \\
\hline GDP & $-7.77^{*}$ & - & $\mathrm{I}(0)$ \\
M2 & 0.24 & $-5.35^{*}$ & $\mathrm{I}(1)$ \\
GCF & $-3.95^{*}$ & - & $\mathrm{I}(0)$ \\
DCPS & 2.99 & $-4.02^{*}$ & $\mathrm{I}(1)$ \\
\hline
\end{tabular}

Source: Authors' calculation by using EViews software.

\section{Granger Causality Test}

The output of the Granger causality test has been presented in the Table 3.

Table 3: Granger Causality Test

\begin{tabular}{lccccc}
\hline \multicolumn{1}{c}{ Variable/Lags } & 1 & 2 & 3 & 4 & 5 \\
\hline \multicolumn{1}{c}{ Null Hypothesis: } & 0.502 & 0.526 & 0.471 & 0.751 & 0.918 \\
\hline GCF does not Granger cause GDP & 0.256 & 0.501 & 0.623 & 0.860 & 0.826 \\
GDP does not Granger cause GCF & 0.444 & 0.707 & 0.721 & 0.849 & 0.590 \\
\hline M2 does not Granger cause GDP & 0.925 & 0.625 & 0.818 & 0.825 & 0.824 \\
GDP does not Granger cause M2 & 0.363 & 0.603 & 0.732 & 0.738 & 0.589 \\
DCPS does not Granger cause GDP & 0.562 & 0.617 & 0.788 & 0.643 & 0.791 \\
GDP does not Granger cause DCPS & 0.055 & 0.122 & $0.036^{*}$ & 0.068 & 0.384 \\
M2 does not Granger cause GCF & 0.925 & $0.006^{*}$ & $0.004^{*}$ & $0.013^{*}$ & $0.005^{*}$ \\
\hline GCF does not Granger cause M2 & & & &
\end{tabular}




\begin{tabular}{lccccc}
\hline DCPS does not Granger cause GCF & $0.039 *$ & 0.102 & 0.090 & 0.169 & 0.085 \\
GCF does not Granger cause DCPS & 0.884 & 0.053 & 0.108 & $0.029 *$ & $0.019 *$ \\
\hline DCPS does not Granger cause M2 & 0.773 & 0.316 & 0.340 & 0.382 & 0.163 \\
M2 does not Granger cause DCPS & 0.147 & 0.066 & 0.118 & 0.142 & 0.096 \\
\hline
\end{tabular}

Source: Authors' calculation by using EViews software.

There is no Granger causality between GCF and GDP; M2 and GDP; DCPS and GDP and DCPS and M2. There is no short run causal relationship from GCF to GDF, M2 to GDP, DCPS to GDP and DCPS to M2. But there is bidirectional Granger causal relationship between M2 and GCF at 3 lags and unidirectional relationship between GCF and DCPS at 4 lags.

\section{Johansen Cointegration Test}

Table 4 shows that there is cointegration among the variables at most 2 level of cointegration.

Table 4: Output of Johansen Cointegration Test

\begin{tabular}{ccccc}
\hline Hypothesized & \multicolumn{3}{c}{ Trace value } & Max-Eigen Value \\
\cline { 2 - 5 } No. of CEs & Statistic & 5\% Critical Value & Statistic & 5\% Critical Value \\
\hline None* & 72.39 & 47.21 & 40.59 & 27.07 \\
At most $1 *$ & 31.80 & 29.68 & 24.82 & 20.97 \\
At most 2 & 6.98 & 15.41 & 5.64 & 14.07 \\
At most 3 & 1.33 & 3.76 & 1.33 & 3.76 \\
\hline
\end{tabular}

Source: Authors' calculation by using EViews software.

* denotes rejection of the hypothesis at $5 \%$ level.

The evidence of such cointegration suggests that three variables are bound together by a long run equilibrium relationship. This is consistent with economic theory as it indicates that economic growth and financial development have a long run equilibrium relationship. Hence, this suggests that causality between the variables must exist at least in one direction. In such circumstances, we can run the vector error correction model (VECM).

\section{Vector Error Correction Model (VECM)}

Since there is cointegration among all the variables, so VECM model (also called restricted VAR model) has been applied for finding out whether there is existence of long run association among the variables or not. The following equation has been developed to estimate VECM:

VECM Equation: D(GDP) $=\mathrm{C}(1) *($ GDP $(-1)-0.086 * \mathrm{M} 2(-1)+0.103 * \mathrm{DCPS}(-1)-2.931$

Breusch-Godfrey Serial Correlation LM Test:

\begin{tabular}{llll}
\hline \hline F-statistic & 0.865967 & Probability & 0.432883 \\
Obs*R-squared & 2.267612 & Probability & 0.321806 \\
\hline \hline ARCH Test: & & & \\
\hline \hline F-statistic & 0.069816 & Probability & 0.793299 \\
Obs*R-squared & 0.074018 & Probability & 0.785574 \\
\hline \hline
\end{tabular}


White Heteroscedasticity Test:

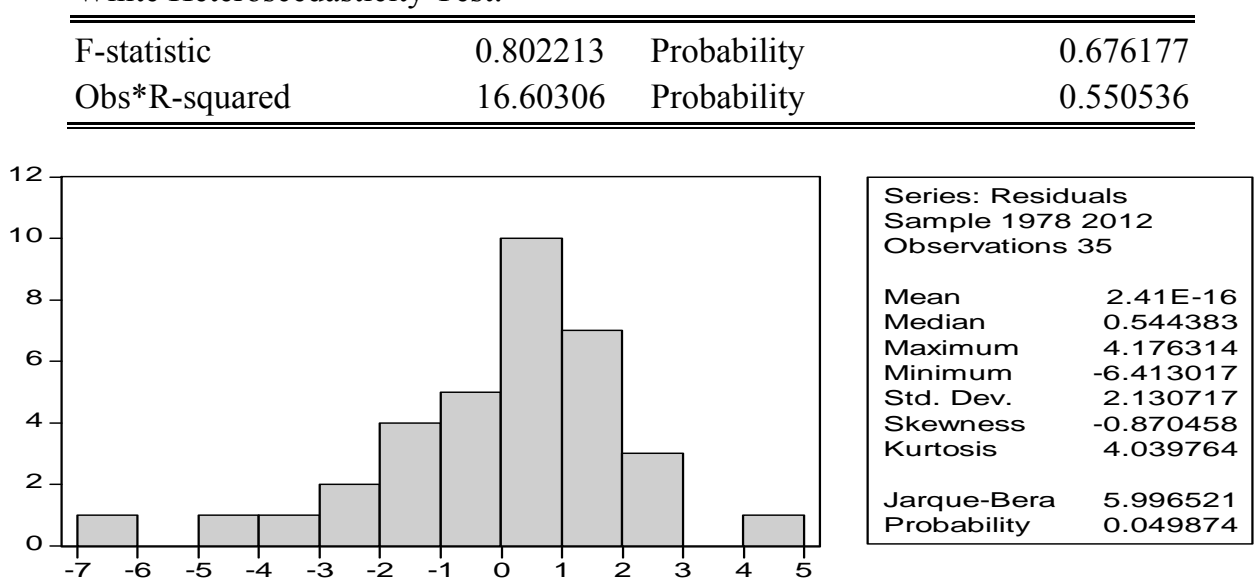

Wald Test: Equation

\begin{tabular}{lrrr}
\hline \hline Test Statistic & Value & df & Probability \\
\hline \hline F-statistic & 1.560821 & $(6,27)$ & 0.1969 \\
Chi-square & 9.364928 & 6 & 0.1541 \\
\hline \hline
\end{tabular}

Source: Authors' calculation by using EViews software.

There is no Heteroscedasticity, no ARCH effect, and no serial correlation in the model but the residuals are not normally distributed (4.99 percent), however it is acceptable. Since the coefficient of error correction term is negative and p-value is also significant that suggest for the validity of the long run association among variables. The Wald test statistics shows that there is no short run causality of M2 and DCPS to the GDP because the p-value of the test (15.41 percent) is greater than 5 percent. The study shows that M2 and DCPS have long run causality to the GDP but there is no short run causality among them. Thus, we can conclude that financial institutions have long run association with economic growth of the nation.

\section{CONCLUSION}

This paper has examined whether financial institutions supports for the economic growth of Nepal or not. The empirical analysis shows that there is existence of long run association among the variables of GDP, M2 and DCPS. The VECM suggests for the validity of the long run association among these variables. There is no granger causality between GCF and GDP; M2 and GDP; DCPS and GDP and DCPS and M2 however, there is bidirectional granger causal relationship between M2 and GCF and unidirectional relationship between GCF and DCPS. Similarly, Wald test statistics does not find any short run causal relationship from M2 and DCPS to the GDP. The research shows that there is a long-run association between financial institutions and economic growth of Nepal. A sound financial system is essential to promote well developed financial institutions that ultimately supports for economic growth of the nation in the long run. The regulatory authority and financial institutions should accelerate financial reforms to improve the 
efficiency of financial system that helps to stimulate adequate capital formation and investment in the productive sectors.

\section{REFERENCES}

Abu-Bader, S. and Abu-Qarn, A. (2008). Financial development and economic growth: empirical evidence from six mena countries. Review of Development Economics, 12(4), 803 - 817.

Balckburn, K. and Hung T. Y. (1996). A theory of growth, financial development and trade, Economica.

Beck, T., Levine, R. and Loyaza, N. (2000). Finance and sources of growth. Journal of Banking and Finance, Vol. 58, 261- 300.

Bhetuwal, K. R. (2007). Financial liberalization and financial development in Nepal. Economic Review, Occasional Paper, Nepal Rastra Bank, 23- 42.

Bhusal, B. P. (2001). Developments and the Current State of Financial System in Nepal. Graduate School of Economics, Kyushu University, 6-19.

Calderon, C. and Liu, L. (2003). The direction of causality between financial development and economic growth. Journal of Development Economics, Vol. 72, 321-324.

Cameron, R., et al. (1967). Banking in the early stages of industrialization: a study in comparative economic history. Oxford University Press. New York.

Demirguc-Kunt, A. and Levine, R. (eds) (2001). Financial structure and economic growth: a crosscountry comparison of banks, markets and development, Cambridge, MA: MIT.

Engle, R. F. and Granger, C. W. (1987). Co-integration and error correction: representation, estimation and testing, Econometrica, Vol. 55, 251-276.

Gelbard, E. A. and Leite, S. P. (1999). Measuring financial development in sub saharan Africa, IMF Working Paper 99/105.

Goldsmith, R. W. (1969). Financial structure and development, New Haven: Yale University Press.

Greenwood, J. and Javanovic, B. (1990). Financial development, growth and the distribution of income, Journal of Political Economy, Vol. 98, 1076- 1107.

Khan, M. S. and Senhadji, A. S. (2000). Financial development and economic growth: an overview, IMF Working Paper 00/209.

Kharel, R. S. and Pokhrel, D. R. (2012). Does Nepal's financial structure matter for economic growth? Economic Review, Nepal Rastra Bank, Vol. 24 (2), 31-46.

King, R., and Levine, R. (1993a). Financial intermediation and economic development. In financial intermediation in the construction of Europe, (ed) by Colin Mayer and Xavier Vibes. London: Center for Economic Policy Research.

King, R. and Levine, R. (1993b). Finance and growth: Schumpeter might be right. Quarterly Journal of Economics, 717-737.

Levine, R. (2004). Finance and growth: theory and evidence. National Bureau of Economic Research Working Paper, retrieved at http://www.nber.org/papers/w107661050.

Maskay, N. M. and Subedi, S. R. (2009). Development of the nepalese financial system: nepal for the formulation of a master plan. Economic Review, Occasional Paper, Nepal Rastra Bank, 31- 51.

Ministry of Finance. Various Issues of Economic Survey. 
Nepal Rastra Bank. Various Issues of Banking and Financial Statistics.

Nepal Rastra Bank. Various Issues of Quarterly Economic Bulletin.

Schumpeter, J. A. (1934). The theory of economic development. Translated by redvers opie, Cambridge MA: Harvard University Press.

Shrestha, M. B. (2005). Financial liberalization in nepal. Unpublished Ph.D. Dissertation, University of Wollongong, New South Wales, Australia.

Westermann, F. (2012). Linkages between sectoral output growth and financial development in Nepal. Economic Review, Nepal Rastra Bank, Vol. 24 (2), 15-30.

Appendix A

Vector Error Correction Model I

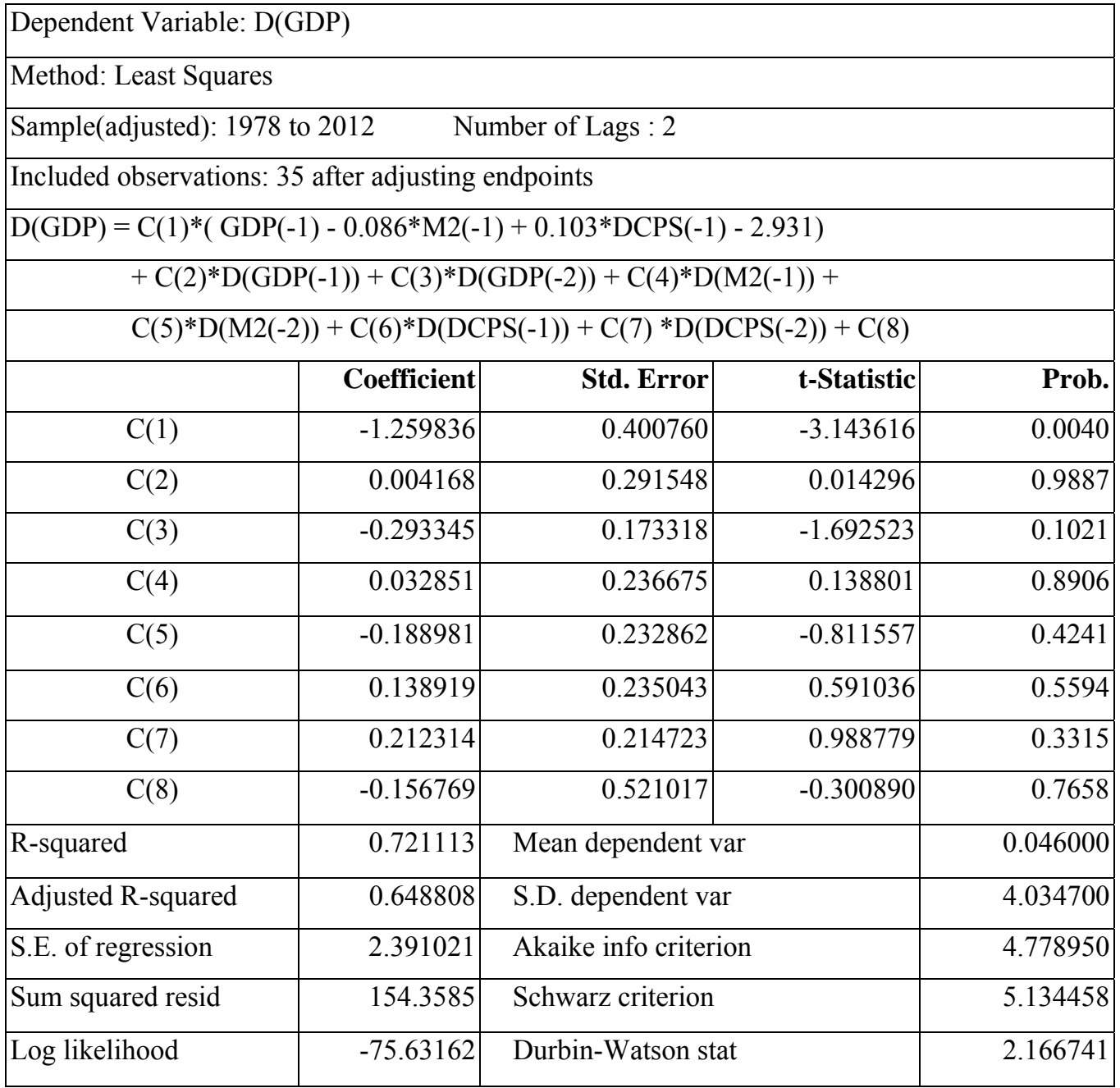

Source: Authors' calculation, using EViews software. 